\title{
Leaching of Picloram in Ultisol under Different Rainfall VOLUMES $^{1}$
}

\author{
Lixiviação do Picloram em Argissolo Vermelho-Amarelo Submetido a Diferentes Volumes de \\ Chuva
}

\begin{abstract}
ASSIS, E.C. ${ }^{2}$, SILVA, A.A. ${ }^{3}$, D’ANTONINO, L. ${ }^{4}$, QUEIROZ, M.E.L.R. ${ }^{5}$ and BARBOSA, L.C. ${ }^{5}$
ABSTRACT - The present study aimed to evaluate the leaching potential of Picloram in Ultisol columns under different rainfall amounts. For such, 30 treatments were evaluated (one soil associated with three levels of rainfall and ten depths).The experiments were arranged in a split-plot design, in a completely randomized design, with four replications. PVC columns of $10 \mathrm{~cm}$ in diameter and $50 \mathrm{~cm}$ in length were filled with these soils, moistened, and placed upright for 48 hours to drain the excess water. The herbicide was applied and rainfall simulations were carried out at specified intensities, according to the treatments, to force Picloram leaching. After 72 hours, all the columns were arranged in a horizontal position and opened lengthwise. Then, soil sampling was carried out every $5 \mathrm{~cm}$ of depth for subsequent herbicide extraction and quantification and analysis by high performance liquid chromatography. The remaining soil samples were placed in plastic pots, and, at the respective depths, the indicator species Cucumis sativus was sown. Twenty-one days after the emergence (DAE) of the indicator plants, evaluations were conducted to verify the symptoms of toxicity caused by Picloram in the plants. It was concluded that Picloram leaching is directly dependent on the volume of rain applied. The herbicide reached the deepest regions in the soil with the highest intensity of rain. The results obtained by bioassay were in agreement with those found by liquid chromatography.
\end{abstract}

Keywords: herbicide, environmental impact, bioassay.

\begin{abstract}
RESUMO - Objetivou-se com este trabalho avaliar o potencial de lixiviação do Picloram em colunas preenchidas com Argissolo Vermelho-Amarelo, submetidas a diferentes volumes de chuva. Para isso, foram avaliados 30 tratamentos (um solo associado a três intensidades de chuva e dez profundidades). Utilizou-se o esquema de parcela subdividida em delineamento inteiramente casualizado, com quatro repetições. A montagem do experimento consistiu em preencher com amostras do solo colunas de PVC de $10 \mathrm{~cm}$ de diâmetro por $50 \mathrm{~cm}$ de comprimento, preparadas para estudos de lixiviação de herbicidas. Essas colunas foram preenchidas com os solos, umedecidas e colocadas na posição vertical por 48 horas para drenagem do excesso de água, aplicando a seguir o herbicida e as chuvas simuladas no topo destas, em intensidades especificadas de acordo com o tratamento, para forçar a lixiviação do Picloram. Setenta e duas horas após a simulação, todas as colunas foram dispostas na posição horizontal e abertas longitudinalmente, realizando-se amostragens de solo a cada intervalo de $5 \mathrm{~cm}$ de profundidade, para posterior extração e quantificação do herbicida e análise por cromatografia líquida de alta eficiência. O restante das amostras de solo de cada intervalo foi colocado em potes plásticos, e, nas respectivas profundidades, semeou-se a espécie indicadora Cucumis sativus. Aos 21 dias após a emergência (DAE) das plantas indicadoras foram realizadas avaliações dos sintomas de intoxicação provocados pelo Picloram. Concluiu-se que o Picloram apresentou lixiviação diretamente dependente do volume de chuva aplicado. O herbicida atingiu regiões mais profundas no solo cuja intensidade de chuva foi maior. Houve boa concordância entre os resultados obtidos pelo bioensaio e o método cromatográfico.
\end{abstract}

Palavras-chave: herbicida, impacto ambiental, bioensaio

1 Recebido para publicação em 10.2.2011 e aprovado em 2.5.2011

2 Licenciado em Química, M.Sc., <emanuelagroufv@hotmail.com>; ${ }^{3}$ D. Sc., Professor Associado, Dep. de Fitotecnia, Universidade Federal de Viçosa - DFT/UFV; ${ }^{4}$ Engo-Agroํㅡㄴ, D.Sc., DFT/UFV; ${ }^{5}$ D.Sc., Professor Associado, Dep. de Química - DEQ/UFV. 


\section{INTRODUÇÃO}

Cattle raising in Brazil is characterized by the large area occupied by pastures, which contributes to the competitive production of meat and milk, in relation to quality and production cost. However, degraded pastures with high weed infestation are a major problem for the Brazilian cattle production system (Santos et al., 2006). There are over 40 million hectares of degraded pastures only in the cerrados (Kluthcouski et al., 2006).

The chemical control of weeds by herbicide application has become one of the most widely used methods due to its low cost and effectiveness. The herbicides 2,4-D + Picloram, fluroxypyr + Picloram and triclopyr are among those registered for pastures in Brazil (Silva et al., 2007).

Picloram is highly active on dicots and is commonly used associated to the herbicides mentioned above. It is persistent in the soil, with half-life of 90 days (Rodrigues $\&$ Almeida, 2005), and can be found until two or three years after spraying in the entire area (Deubert \& Corte-Real, 1986; WSSA, 1994). According to Inoue et al. (2003), due to its long persistence, this herbicide is considered to present high potential for groundwater contamination.

A major problem associated with the use of pesticides highly mobile in the soil is the contamination of surface and groundwater. Anionic herbicides, such as Picloram, are particularly problematic because they are poorly retained by most soil components and sediments and can be easily dissolved in soil solution (Celis et al., 2002), which makes them subject to leaching.

The leaching process is the downward movement of herbicides in soil matrix due to water flow. Its intensity depends on the interactions between the physical and chemical properties of the product, soil and climate. Thus, the properties of the soil, such as organic matter content, percentage and type of clay, cation exchange capacity, total sum of exchangeable bases and $\mathrm{pH}$, directly affect the sorption of these compounds in the soil and their potential for leaching and contaminating groundwater (Biggar \& Cheung, 1973; Celis et al., 2002, Silva et al., 2007).
Many authors consider that environmental monitoring programs, implemented through well-designed field studies, are good procedures for evaluating and minimizing groundwater pollution (Cohen et al. 1995; Albanis et al. 1998; Azevedo et al. 2000; Filizola et al., 2002). These studies can be conducted by direct analysis of water and/or soil, since the potential for groundwater contamination by pesticides depends on their mobility in the soil.

However, these assessment techniques demand equipment with very high maintenance costs. An alternative technique is the use of deformed soil columns with sowing of plant species that are highly sensitive to the herbicide of interest, called biomarkers (Inoue et al., 2007).

The objective of this work was to evaluate the leaching potential of Picloram in Red-Yellow Argisol, by biological and chromatographic methods, using deformed soil columns subjected to different amounts of rain.

\section{MATERIAL AND METHODS}

Samples of Red-Yellow Argisol were collected at depths from 0 to $20 \mathrm{~cm}$ in Viçosa, Minas Gerais, in an area of degraded pasture, where no herbicide had been applied. The soil was sieved in $10 \mathrm{~mm}$ mesh and stored in a polyethylene box. The sample was subjected to physical-chemical analysis and textural classification (Table 1).

The soil samples were placed in PVC columns with $10 \mathrm{~cm}$ internal diameter and $50 \mathrm{~cm}$ of length, to which paraffin had been previously applied internally, to prevent internal lateral draining of the water to be used for Picloram leaching. These columns had removable side cover and were marked every $5 \mathrm{~cm}$. A nylon mesh with filter paper was placed at their lower base to prevent soil loss. Each column was filled with approximately $3.5 \mathrm{~kg}$ of moist soil close to field capacity and remained at rest for 24 hours for draining the excess water. Picloram was applied at the top of the column, at a dose of $720 \mathrm{~g} \mathrm{ha}^{-1}$, equivalent to $3 \mathrm{~L} \mathrm{ha}^{-1}$ of the commercial product (Padron $\mathbb{R}$ ). It was used a $\mathrm{CO}_{2}$ pressurized backpack sprayer equipped with two XR 110.02 nozzles spaced $50 \mathrm{~cm}$, maintained at 2.5 bar pressure. 
Table 1 - Physical-chemical characterization and textural classification of the soil sample used in the experiment. Viçosa-MG

\begin{tabular}{|c|c|c|c|c|c|c|c|c|c|c|c|}
\hline \multicolumn{12}{|c|}{ Granulometric analysis } \\
\hline \multicolumn{2}{|c|}{ Soil } & Clay & Silt & \multicolumn{2}{|c|}{ Fine sand } & & oarse sand & \multicolumn{4}{|c|}{ Textural classification } \\
\hline AVA & \multicolumn{2}{|r|}{26} & 16 & \multicolumn{2}{|c|}{29} & & 29 & \multicolumn{4}{|c|}{ Sandy-clay loam } \\
\hline \multicolumn{12}{|c|}{ Chemical analysis } \\
\hline \multirow{2}{*}{ Solo } & $\mathrm{pH}$ & $\mathrm{P}$ & $\mathrm{K}^{+}$ & $\mathrm{Ca}^{++}$ & & & $\mathrm{H}+\mathrm{Al}$ & $\mathrm{CTC}(\mathrm{T})$ & V & $\mathrm{m}$ & $\mathrm{MO}$ \\
\hline & $\left(\mathrm{H}_{2} \mathrm{O}\right)$ & \multicolumn{3}{|c|}{$\left(\mathrm{mg} \mathrm{dm}^{-3}\right)$} & \multicolumn{4}{|c|}{$\left(\mathrm{cmol}_{\mathrm{c}} \mathrm{dm}^{-3}\right)$} & \multicolumn{2}{|c|}{$(\%)$} & $\left(\right.$ dag kg $\left.^{-1}\right)$ \\
\hline AVA & 4.96 & 12.1 & 61 & 3.2 & & & 4.79 & 4.96 & 51 & 0 & 3.10 \\
\hline
\end{tabular}

Analyses conducted at the Laboratório de Análise de Solo e Folha Viçosa Ltda (Laboratory of Soil and Leaf Analysis Viçosa Ltda), according to the methodology of the Empresa Brasileira de Pesquisa Agropecuária - Embrapa (1997) (Brazilian Agricultural Research Corporation - Embrapa).

Then, the columns were taken to the greenhouse of the Department of Crop Science of the Universidade Federal de Viçosa, where they were kept during the experimental period. Immediately after herbicide application, rainfall events were simulated for 20,40 and $80 \mathrm{~mm}$, according to the specific treatment. The rainfall simulation was monitored by a pluviometer attached to the top of the columns in order to control the desired amount of rain. After rainfall simulation, the columns were left at vertical position for 72 hours for the complete percolation of the water in them.

Then, the columns were placed horizontally. Their side panels were removed, and the soil sampling was carried out so that all soil content at each depth (5 cm divisions) was transferred to plastic bags, where it was homogenized and dried.

Part of the soil was then subjected to extraction and analysis by liquid chromatography. The remaining was subjected to a bioassay, which consisted of transferring the soil to plastic pots and later sowing three seeds of cucumber (Cucumis sativus) as a bioindicator plant. The pots were regularly irrigated to allow good plant growth.

Thirty treatments were evaluated: three volumes of rain $(20,40$ and $80 \mathrm{~mm})$ and 10 depths $(0-5,5-10,10-15,15-20,20-25,25-$ $30,30-35,35-40,40-45$ and $45-50 \mathrm{~cm}$ ) in a completely randomized design with four replications. Columns free from Picloram were also mounted for each volume of rain, for visual comparison.
The assessment of the rate of plant intoxication by the herbicide was performed 21 days after their emergence, and scores from 0 (no toxicity) to 10 (plant death) were determined.

The technique of solid-liquid extraction proposed by Cheng (1969) was adapted and used for the extraction of Picloram from soil samples. In this technique, $2.00 \mathrm{~g}$ of soil were air dried, passed through a sieve mesh with $2.0 \mathrm{~mm}$ pores and were placed in plastic tubes with conical bottom and screw cap. Next, $20.0 \mathrm{~mL}$ of a $\mathrm{KCl}$ solution were added to the concentration of $0.5 \mathrm{~mol} \mathrm{~L}^{-1}$. The flask was shaken in a vortex agitator for 10 seconds to form the suspension, whose $\mathrm{pH}$ was adjusted to 7.0 , with drops of $\mathrm{KOH} 0,1 \mathrm{~mol} \mathrm{~L}^{-1}$ alkaline solution.

Thereafter, the system was shaken in vertical agitator for 60 minutes. Then, it remained at rest for 10 minutes. Next, the bottles were centrifuged for 10 minutes at $3,500 \mathrm{rpm}$.

After the settling of soil particles and cleaning of the extract, $1.5 \mathrm{~mL}$ of the supernatant was removed and transferred to a $5.0 \mathrm{~mL}$ glass syringe with a $0,45 \mu \mathrm{m}$-pore Millipore filter. Finally, the contents of the syringes were filtered directly into $1.8 \mathrm{~mL}$ glass vials and analyzed by high performance liquid chromatography equipped with UV-vis detector.

The technique proposed by Cheng (1969) has been optimized and some validation parameters proposed by Anvisa (2003), Inmetro (2003) and Ribani et al. (2004) were 
also evaluated, including selectivity, linearity of detector response, limits of detection (LOD) and quantification (LOQ), precision and accuracy.

The stock solution (100 $\left.\mathrm{mg} \mathrm{L}^{-1}\right)$ and the working solutions at different Picloram concentrations were prepared using analytical standard in a solution of acetic acid $25 \%$, stored in a dark place at room temperature.

The soil samples were fortified with the active principle at increasing concentrations ( $\left.\mu \mathrm{g} \mathrm{L}^{-1}\right)$, for the construction of the analytical curve. Next, they were subjected to the extraction method. The concentrations of the extracts ranged from 2.0 to $100.0 \mu \mathrm{g} \mathrm{L}^{-1}$. The extracts were then injected, and the analytical curve was obtained, relating the concentrations of Picloram to their respective areas. The analyte quantification was carried out based on the equation of the line obtained by the analytical curve of the method.

A Shimadzu SPD 20A High Performance liquid chromatograph and a Shimadzu VP- ODS Shim-pack stainless steel column, $150 \mathrm{x}$ $4.6 \mathrm{~mm}$ i.d, at constant temperature of $26^{\circ} \mathrm{C}$, were used for the determination of Picloram. The mobile phase consisted of a mixture of aqueous solution of $4 \%$ acetic acid and acetonitrile $(85: 15, \mathrm{v} / \mathrm{v})$, previously filtered through a membrane of $0.45 \mu \mathrm{m}$, eluted in isocratic mode with a flow of $1.2 \mathrm{~mL} \mathrm{~min}^{-1}$. Pesticide detection was performed at $254 \mathrm{~nm}$.

The data were subjected to the analysis of variance, tests of means and regression analysis, with a significance level of $5 \%$, to interpret the results. The biological response and the significance of the model were considered for the selection of the models.

\section{RESULTS AND DISCUSSION}

Validation studies must be representative and should be conducted in a way to allow appropriate variation in the concentration range and types of samples. According to the applied dose, equivalent to $720 \mathrm{~g} \mathrm{ha}^{-1}$, which corresponds to three times the recommended dose in soil columns, with approximately 3.5 kilograms, if there were perfect homogeneity of the herbicide into the soil contained in the column, the herbicide concentration would be about $161.4 \mu \mathrm{g} \mathrm{kg}^{-1}$. As the process of dissipation of the herbicide into the soil is heterogeneous and uneven, the concentrations found in some points could be lower or higher than the estimated value. Therefore, the 2.0 to $100.0 \mu \mathrm{g} \mathrm{kg}^{-1}$ interval was selected as the working range, which refers to 20.0 to $1000.0 \mu \mathrm{g} \mathrm{kg}^{-1}$.

The main parameters evaluated in the validation process of the analytical method are described in Table 2, where it is observed that the values are in accordance with what is described in literature for the analysis of pesticides (INMETRO, 2003; Ribani et al., 2004): average recovery between 70 and $120 \%$ and $\mathrm{CV}<20 \%$.

Figure 1 shows the chromatograms corresponding to the matrix extract free from herbicide and the $50.0 \mu \mathrm{g} \mathrm{L}^{-1}$ standard of Picloram prepared in the extract of the herbicide matrix studied.

Comparing the chromatograms obtained by the extract of matrix free from herbicide (white) and the one obtained by the standard prepared in the matrix extract, it is clear that the peak present at the retention time of 8.10 min refers to Picloram, which makes the technique selective. Analyte identification was made by comparing the retention times. The quantification of the herbicide in the real samples was performed based on the standard curve (Figure 2).

Table 3 shows the quantification of Picloram in PVA soil samples at different depths, in the columns subjected to different intensities of rain.

Picloram leaching through soil columns was affected by the rain volume applied. It was possible to quantify the herbicide to a depth of

Table 2 - Parameters assessed in the process of the analytical method validation

\begin{tabular}{|l|c|}
\hline Detection Limit (LD) $\mu \mathrm{g} \mathrm{kg}^{-1}$ & 20.0 \\
\hline Quantification Limit (LQ) $\mu \mathrm{g} \mathrm{kg}^{-1}$ & 66.0 \\
\hline Recovery Percentage (\%) & 95.94 \\
\hline Variation Coefficient (\%) & 2.32 \\
\hline Analytical Curve & $\mathrm{y}=221.9 \mathrm{x}-270.9$ \\
\hline Determination Coefficient $\left(\mathrm{r}^{2}\right)$ & 0.999 \\
\hline
\end{tabular}



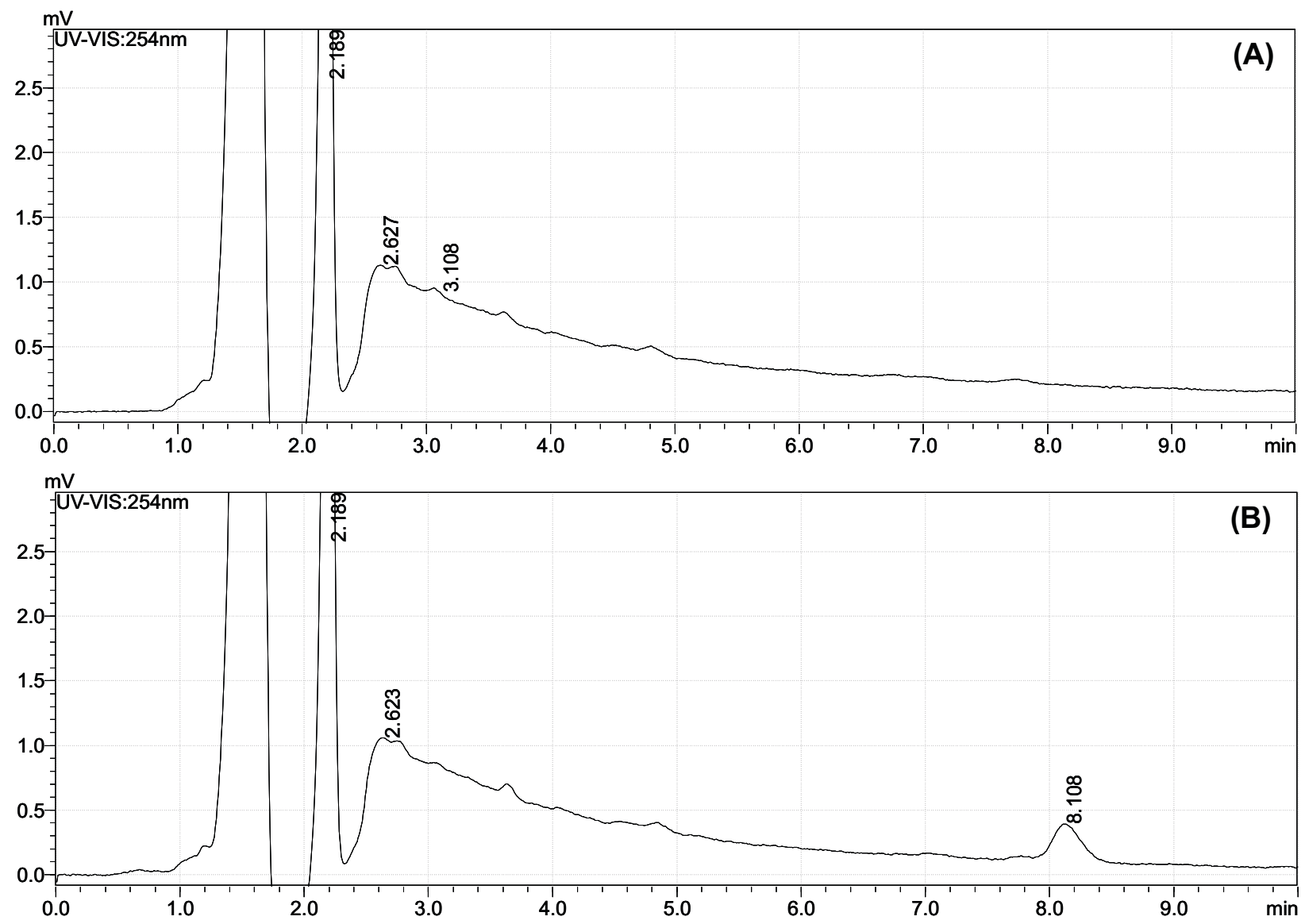

Figure 1 - Response of the detector according to time in minutes. (A) Chromatogram of the extract obtained from AVA soil free from the herbicide and (B) chromatogram of the same soil fortified with $50.0 \mu \mathrm{g} \mathrm{L}-1$ of the herbicide under study, with a retention time of 8.10

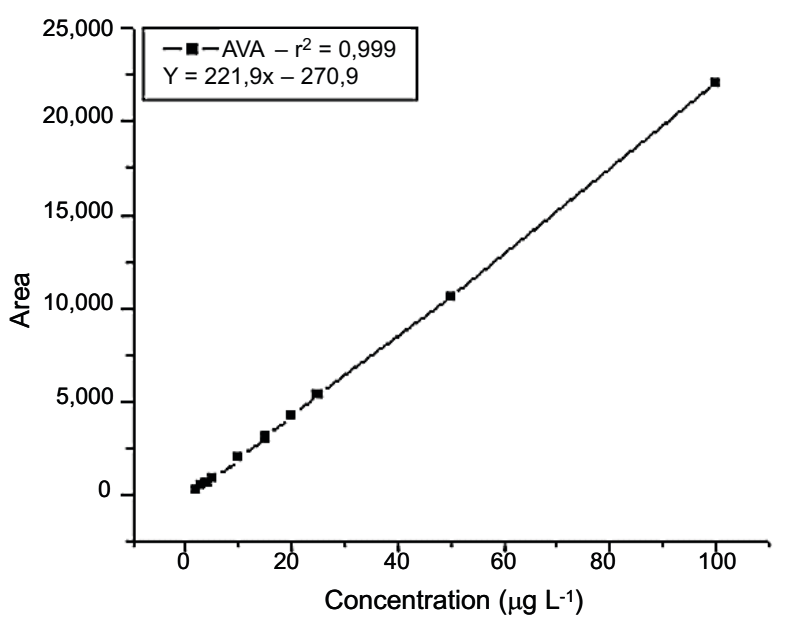

Figure 2 - Picloram standard-curve obtained by injecting extracts achieved by fortified samples at concentrations from 2.0 to $100.0 \mu \mathrm{g} \mathrm{L}{ }^{-1}$, subjected to the method proposed and determined by high performance liquid chromatography (HPLC).
10,15 and $25 \mathrm{~cm}$ in the columns subjected to 20, 40 and $80 \mathrm{~mm}$ of rain, respectively. It was observed clear displacement of the herbicide through the soil.

Similar results were observed when the biological method (Figure 3) was applied. It can be seen in Figure 3 that the percentage of intoxication in the plants ranged from 90 to $100 \%$ for the depths already indicated. No toxicity was observed in plants grown in soil samples from other depths of the respective columns. These results corroborate that biological test can be used as a rapid test for leaching of this herbicide in soil profile (D'Antonino et al., 2009). Intoxication was also observed in the indicator plants at depths where it was possible to detect and quantify the herbicide by chromatography. Visual analysis was performed 21 days after plant emergence (Figure 4). 
Table 3 - Picloram concentration in $\mu \mathrm{g} \mathrm{kg}^{-1}$, determined by high performance liquid chromatography, in soil samples collected at different depths of the columns after simulated rainfall

\begin{tabular}{|c|c|c|c|c|c|c|c|}
\hline \multirow{2}{*}{$\begin{array}{l}\text { Volume of } \\
\text { rainfall }(\mathrm{mm})\end{array}$} & \multicolumn{6}{|c|}{ Depth $(\mathrm{cm})$} & \multirow{2}{*}{$\begin{array}{c}\text { Total } \\
\text { Concent } \\
\left(\mu \mathrm{g} \mathrm{kg}^{-1}\right)\end{array}$} \\
\hline & $0-5$ & $5-10$ & $10-15$ & $15-20$ & $20-25$ & $25-50$ & \\
\hline 20 & 647.7 & 99.5 & ND & ND & ND & ND & 747.2 \\
\hline 40 & 476.8 & 250.3 & 65.2 & ND & ND & ND & 792.3 \\
\hline 80 & 160.2 & 138.0 & 207.6 & 174.1 & 60.9 & ND & 740.8 \\
\hline
\end{tabular}

$\mathrm{ND}=$ non-detected

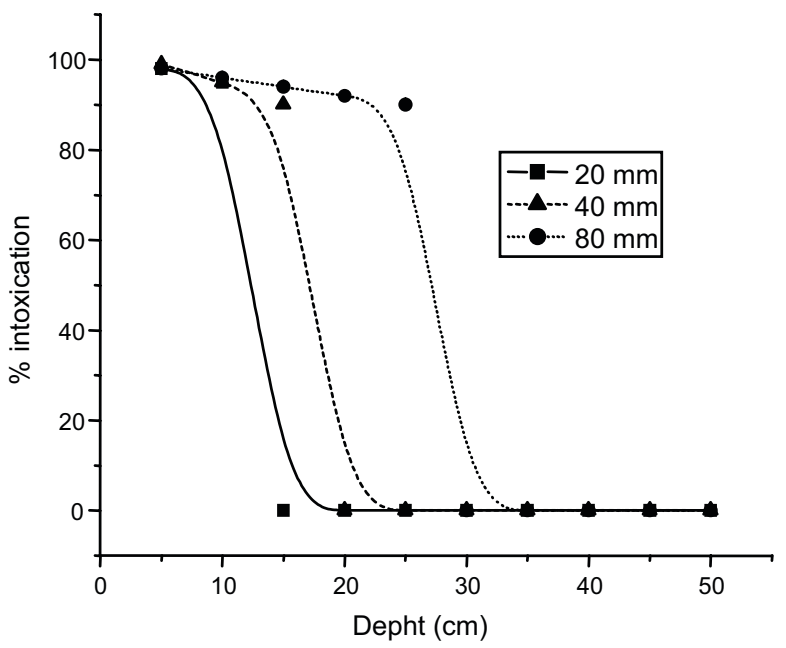

Figure 3 - Percentage of intoxication of cucumber plants grown in samples of Red-Yellow Argisol, for different depths of the columns, after application of Picloram and simulation of 20, 40 and $80 \mathrm{~mm}$ of rain. Viçosa-MG. 2007.

The comparison between the bioassay and the chromatographic method, under the conditions of this study, revealed that the lowest concentration that was necessary to cause intoxication in cucumber plants was equivalent to $60 \mu \mathrm{g} \mathrm{kg}^{-1}$ of soil.

The data that were obtained and the high persistence of Picloram in the soil led to the conclusion that this herbicide can reach long depths and contaminate groundwater in heavy rain season or periodic rainfall. It demonstrates the importance of the cautionary measures involved in the application of herbicides, such as proper dosing, observation of weather conditions, equipment and skilled laborers (Silva et al., 2007).

According to the US Environmental Protection Agency (USEPA, 1999), Picloram mobility is considered intermediate to very mobile in most soils. It can be leached in alkaline and highly permeable soils and those with low organic matter content. Studies conducted by the US Geological Survey (USGS, 1998) revealed the presence of residues of Picloram in 0.11 to $0.20 \%$ of the surveyed groundwater. The maximum level detected was $2.2 \mu \mathrm{g} \mathrm{L}^{-1}$. According to Stoner et al. (1998), this pesticide was detected in $3 \%$ of the groundwater samples in the Red River basin in the state of Minnesota, North Dakota and South Dakota, at concentrations below $10 \mu \mathrm{g} \mathrm{L}^{-1}$. It was observed the leaching of this herbicide over the entire column prepared with the four soils investigated, in studies conducted by Celis et al. (2005), which evaluated Picloram leaching in four different soils from different climatic regions of Europe, with $\mathrm{pH}$ ranging from 6.3 to 7.3. Major Picloram leaching is related to its long persistence and low sorption in most soils.

The results are in agreement with those reported by Celis et al. (2005) and D'Antonino et al. (2009). Picloram mobility is highly dependent on the organic matter content and soil $\mathrm{pH}$. According to Cheung \& Biggar (1974), at $\mathrm{pH}$ above 5.0 , about 95.2 to $100.0 \%$ of the Picloram molecules will be the anionic species. Thus, the molecules will be less absorbed by the negative particles of clay and soil organic matter. They will be present in the soil solution and more likely to be leached.

Brazil has many different types of soils due to its large territory, but Latosols and Argisols prevail in pasture areas, where this herbicide is widely used. According to Hamarker et al. (1968), higher contents of organic matter in the soil decrease the movement of Picloram to greater depths by leaching. Considering that most soils occupied by pastures have 


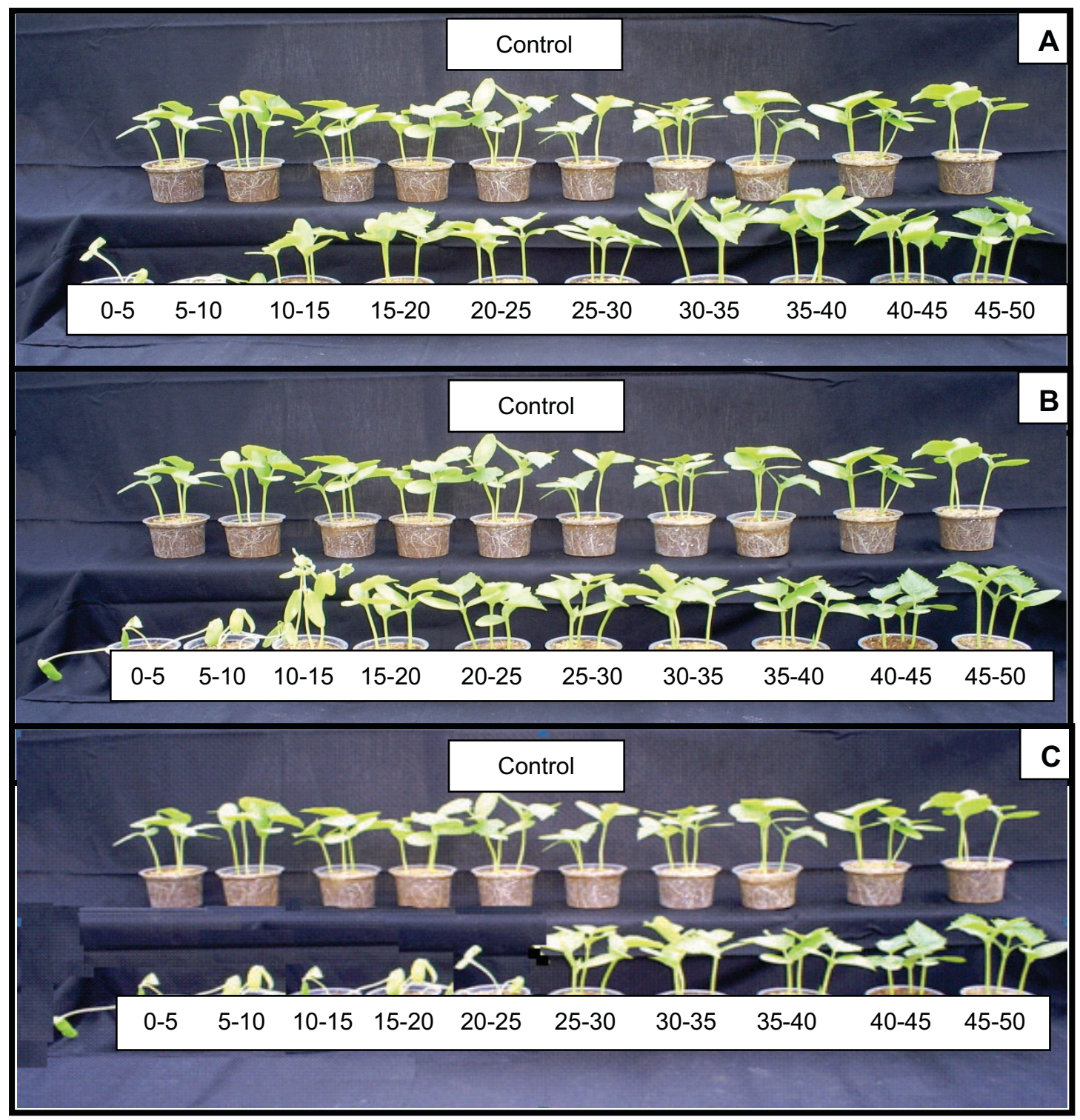

Figure 4 - Intoxication in cucumber plants in soil treated with Picloram and collected at different depths in leaching column, after simulation of 20 (A), 40 (B) and 80 (D) $\mathrm{mm}$ of rain.

little vegetation cover due to inadequate management of these areas and that they are highly weathered, the application of Picloram should be conducted with technical expertise. Therefore, caution is required to avoid contamination of surface and groundwater and toxic effect (carryover) on succeeding and/or adjacent crops.

Picloram, a herbicide widely used against weeds in pasture, presented leaching directly related to the volume of rain applied. This herbicide reached the deepest regions in the soil columns with the highest intensity of rainfall. The results obtained by bioassay, using cucumber, agreed with those achieved by gas chromatography. Wherever intoxication in plants was observed, it was also possible to detect and quantify the herbicide studied.

Picloram application without technical knowledge and previous planning, use of noncalibrated equipment, unskilled labor force and failure to observe the weather can lead to serious surface water and groundwater contamination. 


\section{LITERATURE CITED}

ALBANIS, T. A. et al. Monitoring of pesticide residues and their metabolites in surface and underground waters of Imathia (N. Greece) by means of solidphase extraction disk and gas chromatography. J. Chromatogr. A., v. 823, p. 59-71, 1998.

AZEVEDO, D. A. et al. Monitoring of priority pesticides and other organic pollutants in river water from Portugal by gas chromatography-mass spectrometry and liquid chromatography-atmospheric pressure chemical ionization mass spectrometry. J. Chromatogr. A., v. 79, n. 1, p. 13-26, 2000 .

BIGGAR, J. W.; CHEUNG, M. W. Adsorption of Picloram (4amino-3,5,6-trichloropicolinic acid) on Paloche, Ephrata, and Palouse soils: a thermodynamic approach to the adsorption mechanism. Soil Sci. Soc. Am. Proc., v. 37, p. 863-868, 1973.

CELIS, R. et al. Clay-herbicide complexes to retard Picloram leaching in soil. Intern. J. Environ. Anal. Chem., v. 82, n. 8-9, p. $503-517,2002$.

CELIS, R. et al. Sorption and leaching behavior of polar aromatic acids in agricultural soils by batch and column leaching tests. Eur. J. Soil Sci., v. 56, n. 3, p. 287-297, 2005.

CHENG, H. H. Extraction and colorimetric determination of Picloram in soil. J. Agr. Food Chem., v. 17, n. 6, p. $1174-1175,1969$.

CHEUNG, M. W.; BIGGAR, J. W. Solubility and molecular structure of 4-amino-3,5,6-trichloropicolinic acid in relation to pH and temperature. J. Agric. Food Chem., v. 22, n. 2, p. 202-206, 1974.

COHEN, S. Z. et al. Offsite transport of pesticides in water mathematical models of pesticide leaching and runoff. International Union of Pure and Applied Chemistry, v. 67, n. 12 , p. 2109-2148, 1995.

D'ANTONINO, L. et al. Lixiviação do Picloram em ArgissoloVermelho Amarelo e Latossolo Vermelho-Amarelo com diferentes valores de pH. Planta Daninha, v. 27, n. 3, p. 589-600, 2009.

DEUBERT, K. H.; CORTE-REAL, I. Soil residues of Picloram and triclopyr after selective foliar application on utility rightsof-way. J. Arboric., v. 12, n. 11, p. 269-272, 1986.

FILIZOLA, H. F. et al. Monitoramento e avaliação do risco de contaminação por pesticidas em água superficial e subterrânea na região de Guaíra. Pesq. Agropec. Bras., v. 37, n. 5, p. $659-667,2002$.
HAMAKER, J. W., et al. Rate of detoxification of 4-amino3,5,6-trichloropicolinic acid in soil. Weed Research, v. 8, p. $46-57,1968$

INSTITUTO NACIONAL DE METROLOGIA NORMALIZAÇÃO E QUALIDADE INDUSTRIAL INMETRO. Orientações sobre validação de métodos de ensaios químicos. 2003. (DOQ-CGCRE-008)

INOUE, M. H. et al. Critérios para avaliação do potencial de lixiviação dos herbicidas comercializados no Estado do Paraná. Planta Daninha, v. 21, n. 2, p. 313-323, 2003.

INOUE, M. H. et al. Potencial de lixiviação de imazapic e isoxaflutole em colunas de solo. Planta Daninha, v. 25, n. 3, p. 547-555, 2007.

KLUTHCOUSKI, J. et al. Cobertura de solo em integração lavoura-pecuária. In: SIMPÓSIO DE PRODUÇÃO DE GADO DE CORTE, 5., 2006. Anais... Viçosa-MG: Universidade Federal de Viçosa, 2006. p. 81-156.

RIBANI, M. et al. Validação em métodos cromatográficos e eletroforéticos. Química Nova, v. 27, n. 5, p. 771-780, 2004.

RODRIGUES, B. N.; ALMEIDA, F. S. Guia de herbicidas. 5.ed. Londrina: Grafmarke, 2005.

SANTOS, M. V. et al. Eficácia e persistência no solo de herbicidas utilizados em pastagem. Planta Daninha, v. 24, n. 2, p. 391-398, 2006.

SILVA, A. A. et al. Herbicidas: classificação e mecanismo de ação. In: SILVA, A. A.; SILVA, J. F., (Eds.). Tópicos em manejo de plantas daninhas. Viçosa-MG: Universidade Federal de Viçosa, 2007. p. 83-148.

Stoner, J. D. et al. Water quality in the Red River of the North Basian, Minnesota, North Dakota and South Dakota, 1992-95. Basin, 1998. (U. S. Geological Survey Circular, 1169)

UNITED STATES ENVIRONMENTAL PROTECTION AGENCY - USEPA. Picloram: Time-Limited Pesticide Tolerances. Federal Reg., v. 64, n. 2, p. 418-425, 1999.

U.S. GEOLOGICAL SURVEY - USGS. Data on pesticides in surface and ground water of the United States, results of the National Water Quality Assessment Program (NAWQA). 1998.

WEED SCIENCE SOCIETY OF AMERICA - WSSA Herbicide handbook. Champaign: 1994. 352 p. 